\title{
A Case Study of Financial Issues about Zhejiang Safun

\author{
Industrial Co., Ltd.
}

\author{
Wen Luo \\ Nanjing University of Science \& Technology, China \\ 1597708734@qq.com
}

\begin{abstract}
With the constant maturity of China's capital market and the sharp increase in stock market turnover, many companies plan to use IPO to make them listed companies, and to supplement cash flow through the vast financing platform of the equity market, to achieve a bigger and stronger company. desire. However, the China Securities Regulatory Commission has high standards and stringent requirements for IPOs of listed companies, and IPOs are not uncommon. This article takes Zhejiang Sanfeng Industry as an example to study the financial problems of its IPO, and provides suggestions for the IPO audit of the listed company in the future.
\end{abstract}

Keywords: IPO failure Financial problem Case study

\section{Introduction}

With the rapid economic development of our country, the development momentum of private enterprises cannot be underestimated. However, with the ever-increasing financial problems of private companies, coupled with the unpredictable market environment and changes in the internal development process of enterprises, private companies are eager to win IPO in order to achieve better development in the market. In the IPO process of private enterprises, how to solve the financial problems encountered by enterprises in the IPO process, improve their own market competitiveness, and deal with the impact from domestic and foreign counterparts has become a common concern of domestic private enterprises.

\section{Background}

Zhejiang Safun Industrial Co., Ltd. is located in the hardware capital of China, Yongkang, Zhejiang Province . The company was established on October 23rd, 2008 by Huang Huifei, Huang Li, two natural persons and Safun Tools. The registered capital is 87 million yuan. The company's main business is the research and development, design, production and sales of special tools for garden tools, and is committed to becoming an internationally leading manufacturer of special tools. The company owns Yongkang Kyushu West Road Branch and Yongkang Fengzhi Technology, a wholly-owned subsidiary. After several times of capital increase and equity transfer, the company's shareholding structure is shown in Figure 1. 


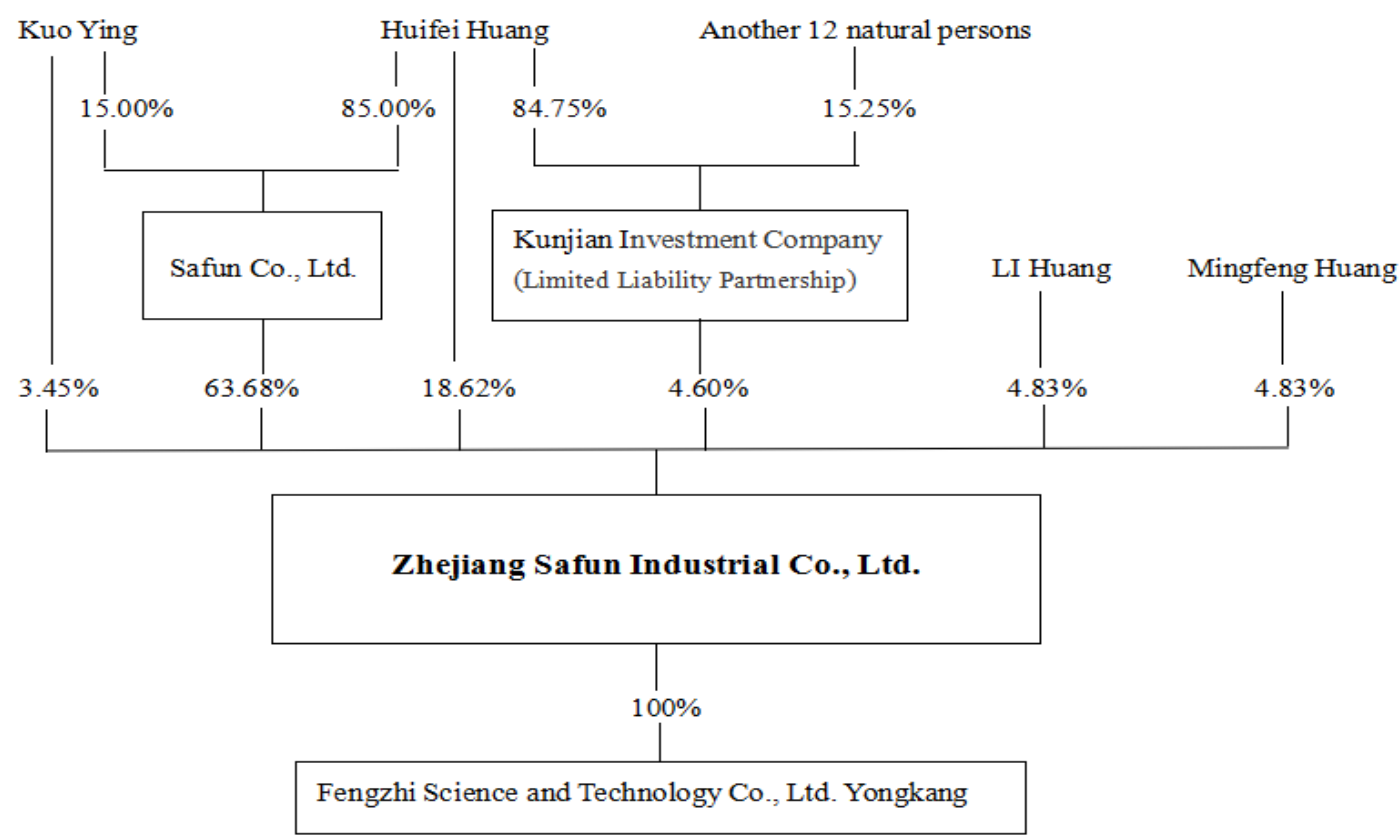

Figure 1 Company's shareholding structure

On June 2, 2017, Safun Industrial disclosed the prospectus on the website of the China Securities Regulatory Commission. The initial application was scheduled to be held on June 14th and is expected to land on the ChiNext of the Shenzhen Stock Exchange. On the evening of the 14th, the "Announcement of the Audit Results of the 48th Meeting of the GEM Board of Approved Development Committees" disclosed on the website of the China Securities Regulatory Commission showed that the initial IPO application of Zhejiang Safun Industrial Co., Ltd. failed.

The area covered by Safun Industrial Products is relatively unpopular, so the company's visibility is not high. However, this does not affect the good performance of Sanfun Industry. From 2014 to 2016, Safun Industrial achieved operating revenue of RMB 432 million, RMB 408 million and RMB 570 million. The net profit for the same period was RMB 20.9744 million, RMB 28.2093 million and RMB 42.121 million. Therefore, Safun Industrial has a certain degree of typicality. The study of whether its IPO has been financed can provide reference for IPOs of other listed companies.

\section{Financial Analysis of Safun Industrial IPO Failure}

\subsection{Excessive connected transactions affect the independence of the company}

The review of connected transactions has always been the focus of the CSRC' s review of the issuer' $s$ initial public offering of shares. Related-party transactions are the transfer of resources, labor or obligations between related parties. Usually, the related parties of an enterprise are its parent company, its subsidiaries, and other companies controlled by the same parent company, and they share the same common The investor that controls, the investor that has significant influence on the enterprise, the joint venture of the enterprise, the associated enterprise of the enterprise, the individual investor of the enterprise, the family members who are closely related to it, and the individual investors of the enterprise. Managers or other family members whose close family members control, jointly control, or 
exert significant influence.

Safun Industrial's related party transactions mainly have the following two problems:

(1) The relationship between shareholders is special

Before the issuance, the company' s total share capital was 87 million shares. The number of shares to be issued in this offering does not exceed 29 million shares, assuming that the number of shares issued this time is 29 million shares, and there is no public offering of shares by shareholders. The equity before and after the company's issuance is shown in table 1:

Table 1 Stocks before and after the company is issued

\begin{tabular}{|c|c|c|c|c|}
\hline \multirow{2}{*}{ Shareholder } & \multicolumn{2}{|c|}{ Before } & \multicolumn{2}{c|}{ After } \\
\cline { 2 - 5 } & $\begin{array}{c}\text { Number of } \\
\text { shares }\end{array}$ & $\begin{array}{c}\text { Shareholding } \\
\text { ratio }\end{array}$ & $\begin{array}{c}\text { Number of } \\
\text { shares }\end{array}$ & $\begin{array}{c}\text { Shareholding } \\
\text { ratio }\end{array}$ \\
\hline Safun Co., Ltd. & 5540 & $63.68 \%$ & 5540 & $47.76 \%$ \\
\hline Huifei Huang & 1620 & $18.62 \%$ & 1620 & $13.97 \%$ \\
\hline Li Huang & 420 & $4.83 \%$ & 420 & $3.62 \%$ \\
\hline Mingfeng Huang & 420 & $4.83 \%$ & 420 & $3.62 \%$ \\
\hline Kunjian Investment Company & 400 & $4.60 \%$ & 400 & $3.45 \%$ \\
\hline Kuo Ying & 300 & $3.45 \%$ & 300 & $2.59 \%$ \\
\hline The shares issued this time & - & - & 2900 & $25.00 \%$ \\
\hline Total & 8700 & $100.00 \%$ & 11600 & $100.00 \%$ \\
\hline
\end{tabular}

Huifei Huang holds 85\% investment of Safun Co., Ltd. and is the actual controller of the company; Huifei Huang holds $84.75 \%$ of Kunjian Investment, and serves as the executive partner of Kunjian Investment; Huifei Huang and Li Huang are siblings; Mingfeng Huang is Huifei Huang's brother; Mingfeng Huang and Li Huang are brothers; Huifei Huang is Kuo Ying's mother.

(2) Connected transactions are suspected of improper delivery of benefits

It can be seen from the prospectus that the formerly existing major affiliates all have directors of Safun Industrial holding important positions. In 2014, the company borrowed funds for Zhejiang Safun Tools Manufacturing Co., Ltd., and the accumulative amount was 35.02 million yuan, and the company accrued interest of 2.301 million yuan. In 2015, the company borrowed funds to Zhejiang Safun Tools Manufacturing Co., Ltd., and the accumulative amount was 47.43 million yuan, and the company accrued interest of 1.6848 million yuan. None of the above related transactions performed the decision-making process. In 2015, the issuer allocated a large amount of cash dividends. The application documents stated that the dividend was mainly due to the fact that the controlling shareholder needed to pay off the balance of funds borrowed from the issuer with the cash dividends it distributed. Safun Industrial also has funds exchanges with some issuer suppliers. Although the application documents explain the reasons for the temporary turnover, there are still doubts about the improper transfer of benefits.

\subsection{Sustained profitability risk}

(1) Raw material price fluctuation risk

The company's main business costs mainly include raw materials, direct labor and manufacturing costs, of which raw material costs accounted for more than $90 \%$ of the main 
business costs, the company' s production of raw materials mainly include guides, chains, carburetor and metal, plastic parts, etc. Therefore, the price fluctuation of raw materials has a greater impact on the company's cost of sales. If there is a major change in the supply of relevant raw materials, or the price fluctuates significantly, it will be detrimental to the company's production budget and cost control, and it will adversely affect the company' $\mathrm{s}$ normal operations in the short term, and thus affect the company's profitability and operating performance.

(2) Over-concentration of profit sources

The company's products are mainly exported to foreign markets through self-export and indirect export through foreign trade companies. Among them, the sales revenue generated by the company' s self-operated exports during 2014-2016 reached 285,749,900, 245,251,100 and $405,566,400$, respectively. The proportion of main business income is $67.50 \%, 61.14 \%$ and $73.13 \%$, respectively. If there is a large fluctuation in the international market, including major changes in the political, economic and social situations and trade policies of the countries and regions where the international market is located, the international market needs The occurrence of major changes and changes in China' s political, economic, and diplomatic cooperation relations will all have a certain impact on the company's overseas operating income, thereby reducing the company's continued profitability.

\section{Suggestions on Regulating Corporate Financial Issues}

\subsection{Reduce related transactions and maintain the independence of the enterprise}

For the listed companies, the related transaction is not impossible, but it needs to meet the conditions that do not affect the independence of the enterprise, the legal compliance of the transaction process, the fair price and so on. On the one hand, we should actively diversify the ownership structure within the company to solve the problem of excessive concentration of equity in the company. The company needs to formulate a reasonable equity balance mechanism to restrict the behavior of the controlling shareholders effectively and reduce the related transactions. On the other hand, for the existing related transactions, we should take measures to reduce the related transactions as much as possible, for example, to transfer the related business to the subsidiary by setting up a subsidiary company by the listed company, and to solve the related transaction through the acquisition of the assets of the related transaction by acquisition; the related transaction can be changed by transferring the shares of the company that produces the related transaction to the non affiliated party. For non related transactions, equity transfer must be fair and market-oriented.

\subsection{Increasing technological innovation to ensure sustainable profitability}

The strong technological innovation ability is the foundation for the company to maintain the competitive advantage and rapid growth. In the process of management, the company should continuously improve its R \& D ability, and increase the development of new products while improving the existing products. Taking the three front industry as an example, the company takes garden tool products as the core direction of technology development. It is necessary to continuously improve the environmental protection, safety and automation of the products, and gradually develop the products of low emission gasoline power garden tools and lithium battery power garden tools. The company should optimize 
and improve products on the basis of existing products, improve product adaptability, and cater to different levels of consumers' multi-level and personalized needs.

\section{Reference}

[1] The Prospectus of Zhejiang Safun Industrial Co., Ltd.

[2]Minghui Ni, The issue of financial issues in the case of issuing audit during IPO. [D]. Hangzhou Dianzi University, 2015.

[3] Danyang Wang. Tianda environmental protection IPO is not a financial problem analysis [J]. Cooperative economy and technology. 2016. 152-153.

[4] Guoju Yao. An analysis of the audit risk of related transactions in the prospectus - based on the first case of Xi'an Longji silicon material Limited by Share Ltd [J]. Financial market. 2012 (07). 36-38.

[5]Zongqing Wang, The common financial problems analysis of IPO[J]. Accounting research. 2017 (09). 133-134. 